\title{
Design and Application of Micro Course in Fundamentals of Computers
}

\author{
https://doi.org/10.3991/ijet.v15i11.14523 \\ Hongxia Liu \\ Yulin University, Shaanxi, China \\ $17719630982 @ 163 . \mathrm{com}$
}

\begin{abstract}
Micro course is an emerging student-centered remote teaching tool. It offers inspirations to the teaching reform of the college course called Fundamentals of Computers. This paper introduces the status quo of the teaching and learning of the said course, and analyzes the application features of micro course, highlighting the advantages of integrating micro course with Fundamentals of Computers. On this basis, the authors established a student-centered micro course teaching system for Fundamentals of Computers, and designed the application mode of the teaching system. Contrastive experiments show that the proposed application mode improves the information awareness of teachers, stimulates the learning interest of students, and promotes the computer skills and information literacy of students.
\end{abstract}

Keywords - Micro course, fundamentals of computers, teaching design, application mode

\section{Introduction}

The reform of Fundamentals of Computers in colleges and universities is in full swing at present, and teachers design and make various kinds of micro course, adopt micro course and on-line teaching, combine with traditional classroom teaching [1], and implement all kinds of micro course - assisted teaching, inverted classroom teaching, blending teaching and other teaching methods.

In foreign countries, the appearance of micro-network teaching videos represented by Khan Academy and TED triggers the educational researchers to explore the feasibility of applying micro-videos to classroom teaching, for example, under the current teaching situation of basic courses of computer culture, they applied the micro course resources to the inverted classroom teaching mode. Li Ping (2019), in the article Research on Application of Inverted Classroom Teaching Design Based on Micro Course in Vocational English Teaching, took grammar knowledge in English teaching in vocational colleges as the starting point, carried out data collection, collation and analysis of the grammar teaching mode in inverted classroom based on micro course, and found that students could learn actively through a series of attempts in inverted classroom teaching design strategies [2]. Several teachers have also applied micro-video resources to blending teaching mode discussions, and they have carried out application studies in 
different courses, which demonstrated this mode is suitable for the subjects with strong operability and practicality. Liu Yajuan et al. (2019) found in the article Experience of Blending Teaching Course Design for Environmental Chemistry Based on Micro course and Inverted Classroom that the structure and difficulty of the course, as well as the assessment of the course, would affect the learning results [3-5]. Through review and summary of the related research literature for nearly three years, it is found that the research of teaching application mode based on micro course has achieved certain results. However, there are still some problems, first of all, most of the research still stays on the theoretical level of teaching mode construction, and take example of one of the classes to carry out simple practice, without systematic comprehensive consideration of teaching input and effect. Secondly, in terms of how the new teaching mode and classroom teaching can be better integrated, the relevant aspects of empirical research still need to be carried out in depth.

In the special period of the national fight against the COVID-19, college students could not return to university on time and could not start university normally. In order to respond to the requirement of "ensuring learning undisrupted when classes are disrupted" put forward by the Ministry of Education, it is of great practical significance to carry out online teaching with the application mode of student-centered micro course teaching. Based on the characteristics of micro course and the present teaching situation of Fundamentals of Computers in colleges and universities, the author designs the micro course teaching system of the course, and systematically expounds the teaching mode based on micro course, which is proved by practice that the mode can promote the renewal of teachers' teaching idea, arouse the students' learning interest, and develop the students to better adapt to the learning way of the information society, cultivate their ability of autonomous learning, and obtain more effective teaching effect.

\section{Teaching and Learning Status Quo of Fundamentals of Computers}

The course of Fundamentals of Computers is a public basic course for non-computer majors in colleges and universities. The purpose of this course is to enable students to understand the basic knowledge of computer science and to skillfully apply commonly used computer software, cultivate students' hands-on practice skills and improve students' information literacy. At present, the course is facing a new challenge.

1. The level of information literacy of our students is varied. Most students come from rural families, and their information knowledge is weak, but with higher learning enthusiasm. A few students have studied the information technology course in middle schools, and learned simple operation. However, their information knowledge is one-sided and lacks systematicness. Therefore, it is difficult for teachers to give consideration to all students, which affects the effects of learning in classroom teaching.

2. It's essential to reduce the class hours, but also improve the teaching quality. At present, this course of our university has been reduced to 60 hours, the teaching content mainly includes the theoretical knowledge module and the operation skill 
module. Therefore, it is necessary for students to make use of the fragmented time to study with the help of information-based means such as micro course [6]. Otherwise, it is difficult to achieve the teaching goal with classroom time alone.

3. It's critical to meet the needs of follow-up courses, but also take into account the needs of post-work. This course is to prepare for the study and graduation thesis of other major courses. In addition, employing units require students to be able to apply commonly used office software skillfully when they are on duty. Therefore, it is necessary to cultivate qualified citizens who have a certain quality of computing thinking and are familiar with the information society of computer application $[7,8]$.

\section{Analysis of Application Characteristics of Micro Course}

\subsection{Concept and characteristics of micro course}

Micro course is a kind of information-based teaching resource, which mainly takes teaching video as the carrier, and can reflect the teaching and learning activities carried out by teachers in the process of teaching for a certain knowledge point or teaching link. Its form of expression is flexible and diverse, and rich in types. All the micro courses are short, small, fine and interesting in terms of features. The short refers to the time of each micro course video takes about 8 to 10 minutes. The small refers to the short video generally involving a knowledge point, a concept, and so on, that's, the content is less and compact, and can be applied to a variety of situations such as online and offline teaching [9]. The fine refers to the content is close to the theme, with exquisite design. And the interesting refers to the design of micro course is vivid and exquisite, as well as interesting to a certain extent.

\subsection{Advantages of the combination of micro course and fundamentals of computers}

The course of Fundamentals of Computers in colleges and universities has stronger operability and practicality. Its main teaching goal is to cultivate students' practical ability. One of the main teaching methods is the demonstration of operation skills. Therefore, the combination of micro course and Fundamentals of Computers can more effectively perform the demonstration and improve the teaching effect [10].

The advantages of the combination of micro course and the course of Fundamentals of Computers are mainly reflected in the following aspects: First, it can help students to study independently. Before teaching, the teacher sends the prepared short video of the micro course to the students through the learning platform, and the students can arrange the pre-class preview according to their own actual situation and time, and can record the problems or questions in practice to facilitate communication with teachers in the classroom [11]. Second, it can effectively promote classroom interaction between teachers and students. In the classroom, teachers can fully understand the key and difficult points and doubts that students encounter in practice, and focus on explaining and demonstrating these problems, which is conducive to students' deep understanding of 
knowledge and skills [12]. Third, it is helpful to consolidate and review after class. Short videos of micro course can be used for both pre-class independent learning and after-class consolidating exercises [13]. Teachers can also send different post-class exercises to students at different levels.

\section{Construction of Micro Course Teaching System of Fundamentals of Computers}

\subsection{Design of teaching system}

Table 1. Contents and Application of Fundamentals of Micro Course Teaching System of Fundamentals of Computers

\begin{tabular}{|c|c|c|c|}
\hline \multirow[b]{2}{*}{ Teaching Contents } & \multicolumn{2}{|c|}{ Topics } & \multirow[b]{2}{*}{ Application } \\
\hline & Compulsory (Basic Content) & $\begin{array}{c}\text { Expansion (select by spe- } \\
\text { cialty) }\end{array}$ & \\
\hline Computer System & $\begin{array}{l}\text { Information Representation, } \\
\text { System Composition, Architec- } \\
\text { ture, Numbering and Transfor- } \\
\text { mation }\end{array}$ & $\begin{array}{l}\text { Operating System Principle, } \\
\text { Embedded System, Memory } \\
\text { Interface }\end{array}$ & $\begin{array}{l}\text { Assisted Teaching } \\
\text { Inverted Classroom }\end{array}$ \\
\hline Computer Network & $\begin{array}{l}\text { Network Fundamentals, Data } \\
\text { Communication Fundamentals, } \\
\text { Network Models and Protocols, } \\
\text { Internet Applications }\end{array}$ & $\begin{array}{l}\text { LAN Technology, Network } \\
\text { Security Technology, Wire- } \\
\text { less Sensor Network }\end{array}$ & $\begin{array}{l}\text { Inverted Classroom } \\
\text { Assisted Teaching }\end{array}$ \\
\hline $\begin{array}{l}\text { Algorithm and Pro- } \\
\text { gram Design }\end{array}$ & $\begin{array}{l}\text { Program and Programming } \\
\text { Language, Algorithm Concept, } \\
\text { Programming Process }\end{array}$ & $\begin{array}{l}\text { Algorithm Design, WEB } \\
\text { Programming Technology, } \\
\text { Mobile Development Tech- } \\
\text { nology }\end{array}$ & $\begin{array}{l}\text { Inverted Classroom } \\
\text { Blending }\end{array}$ \\
\hline \multirow{3}{*}{ Word Operation } & 1: Character formatting & \multirow{3}{*}{$\begin{array}{l}\text { Long Document Typesetting } \\
\text { Mail Merge }\end{array}$} & \multirow{3}{*}{ Blending } \\
\hline & $\begin{array}{l}\text { 2: Table and picture typeset- } \\
\text { ting }\end{array}$ & & \\
\hline & $\begin{array}{l}\text { 3: Mixed arrangement of pic- } \\
\text { tures and texts }\end{array}$ & & \\
\hline \multirow{2}{*}{ Excel Operation } & 1: Cell reference & PivotTable & \multirow{2}{*}{ Blending } \\
\hline & 2: Data processing & Data Analysis & \\
\hline PPT Operation & Basic Operations & Master Application & Blending \\
\hline Network Application & $\begin{array}{l}\text { Send and receive mail } \\
\text { Information retrieval }\end{array}$ & Cloud Disk Usage & $\begin{array}{l}\text { Inverted Classroom } \\
\text { Blending }\end{array}$ \\
\hline
\end{tabular}

In view of the status quo of teaching and learning and the teaching goal requirements of Fundamentals of Computers, a three-level teaching system is designed and constructed in consideration of the characteristics and concrete implementation of the micro course, as shown in Table 1. This system can support the blending learning mode, the mobile learning mode, the inverted classroom and other learning modes advocated by our university at present [14]. 


\subsection{Design and making of topic selection for micro course}

The topic of the micro course is the compulsory teaching content in Table 1, which is the key and difficult points in the course, and can also be the expanded content in the course, generally choosing an independent knowledge point or a demonstration case.

The design of micro course is the most important link. Firstly, the teaching objectives of the micro course are determined, then the appropriate teaching strategies and methods are determined according to the type of knowledge points selected by the micro course, and finally the corresponding teaching schemes of the micro course are determined, such as screen recording type, animation demonstration type, classroom records or others. In the design, the students' learning psychology and their learning habits should be taken into consideration. The designed teaching strategies should adopt taskdriven, problem-oriented and other strategic activities as much as possible to stimulate the students' learning interests and thinking [15]. Second, it's essential to pay attention to the combination of the topic content and practical application, for instance, for the materials used, courseware, comments and others, it's necessary to fully consider the actual application environment and the actual needs of teaching, and constantly enrich and update the content.

The form of making the micro course depends on the type of the micro course designed in the early stage. The micro course of Fundamentals of Computers mainly focuses on operation demonstration, which can be made by means of software recording, or with portable recording equipment. For the micro course of explanation or demonstration, the combination of virtual and real recording can also be adopted.

\section{Discussion on the Application Mode of Micro Course Teaching in Fundamentals of Computers}

According to the test of computer level in the first practice class after the freshmen entered the university, the results show that the students have one-sided knowledge, lack of theoretical knowledge, have relatively good understanding of the basic operation of the system, but relatively weak understanding of electronic form and data processing. Therefore, the prepared micro course resources are provided to the students through the unified platform [16], to explore the application mode of micro course teaching which is suitable for Fundamentals of Computers.

\subsection{Teaching goal and concrete implementation plan}

After applying the micro course resources to the course, two levels of goals have been achieved.

The first level is that the micro course videos are sent to the students according to the course schedule, with assisted teaching in the classroom as well as inverted classroom teaching, thus enriching the classroom teaching form, arousing the students' learning enthusiasm and improving the efficiency of classroom teaching under the premise of reducing the class hours [17]. In the practical class, the students can watch 
the demonstration videos repeatedly, and in the classroom, the teachers can check for the common problems existing among the students, and implement effective teaching.

The second level, i.e., expansion series of micro course resources, is aimed at providing resources to the students of different majors with the good foundation and study enthusiasm, and teachers can timely guide them to expand knowledge, develop independent learning ability and skills to solve problems and help them develop good information literacy.

\subsection{Teaching organization and the interaction between teachers and students}

Micro course resources can be used before, during and after class, that's, students can use all idle time to learn anytime and anywhere [18]. In terms of teaching organization, teachers can guide the students through the teaching platform such as Xuexitong, Yuketang and DingTalk to study the micro course according to the course schedule and their own actual situation, completes the homework arranged by the teacher, or to carry on the group cooperation study with dormitory as unit. Teachers can collect the feedback information of the students through the teaching platform and interact with the students in time, in a bid to promote students to study actively and individually.

\subsection{Teaching evaluation system}

In order to support the further popularization of this new teaching mode, the original method of comprehensive performance evaluation of students is obviously not conducive to arousing the enthusiasm of students. Therefore, on the basis of the original evaluation method, the comprehensive performance evaluation of students is given a new method of quantification. The new evaluation system focuses more on the evaluation of the students' learning process, and quantifies the students' regular learning process into regular results, and adjusts the proportion of comprehensive results from $30 \%$ to $60 \%$. Through the learning platform, the learning situation of students' micro-videos can be monitored, and the students' online learning time, visits, online questions, participation in discussions, online tests, answering questions, etc. can be weighted as part of the quantification of students' regular results [19]. In this way, students are mobilized to use fragmented time for online learning, so that the process of learning takes place at ordinary time, not in the time fighting for the final exam.

\section{$6 \quad$ Research Results and Discussion}

This study first counted the performance evaluation method of 54 students in the experimental group, as shown in Fig. 1. This method pays more attention to the evaluation of the students' learning process, such as the students' performance in the course at ordinary time, the situation of independent learning, and the study results at ordinary time, which accounts for $60 \%$ of the comprehensive results. This evaluation method actually requires classroom teaching to be student-oriented, changing the previous teacher-instilled teaching method [20]. It pays more attention to the characteristics of 
students, mobilizes their enthusiasm for learning, encourages students to study actively, and discovers their own advantages and disadvantages. As shown in Fig. 2, the statistical results show that nearly $80 \%$ of the students agree with this performance evaluation method and show that they are really involved in this blending learning environment and have benefited a lot.

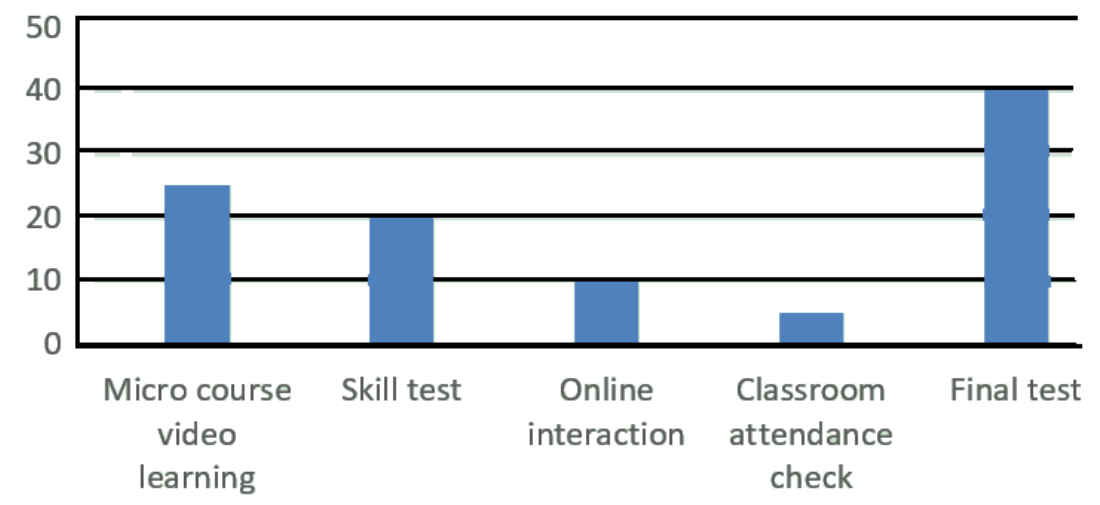

\section{- Comprehensive results}

Fig. 1. Comprehensive performance evaluation method for students in experimental group

Secondly, this kind of micro course teaching application mode pays great attention to the integration with the classroom, and as a core teaching resource, the micro course video plays different important roles in the classroom with various tasks, such as preclass learning, core concept teaching, operation demonstration, after-class practice and other links. As shown in the statistics in Fig. 3, the overwhelming majority of students are willing to understand the learning content before class, indicating that they are willing to become active learners, with strong learning enthusiasm [21]. Fig. 4 shows the situation that students need to practice and consolidate their knowledge after class and the data show that about $68 \%$ of them have used micro course resources to practice. Therefore, in the concrete teaching practice, we should position the micro course as an important supplementary and expansion resource for traditional classroom learning. Relying on the traditional classroom, teachers should give full play to the guiding role in teaching, pay attention to the teaching design of micro course, carefully analyze the needs of students, and make efforts to design micro course resources in combination with teaching tasks. 


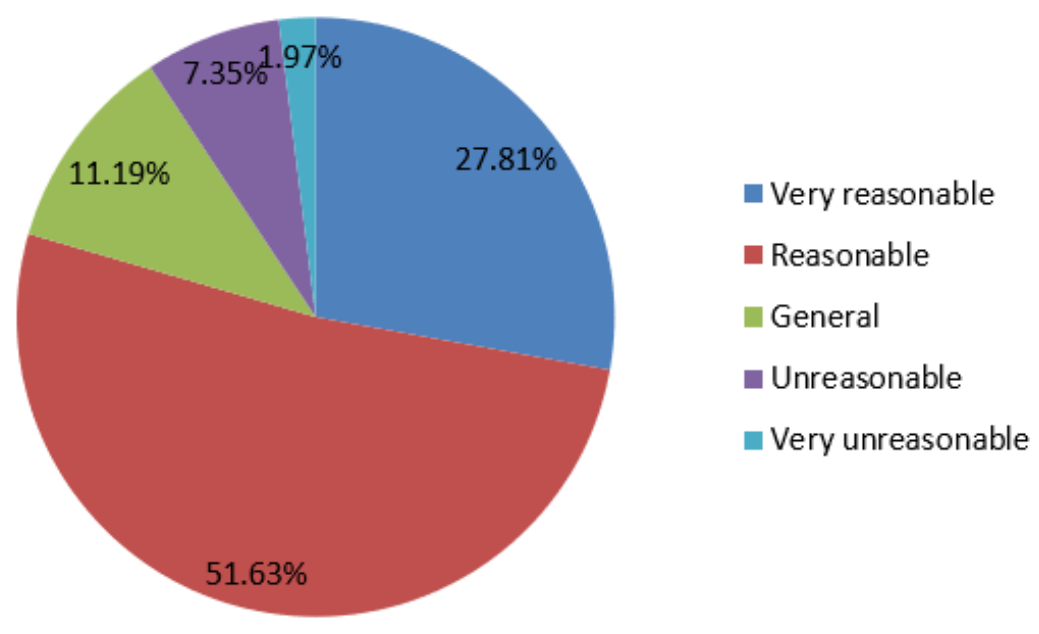

Fig. 2. Evaluation of course evaluation method for students in experimental group

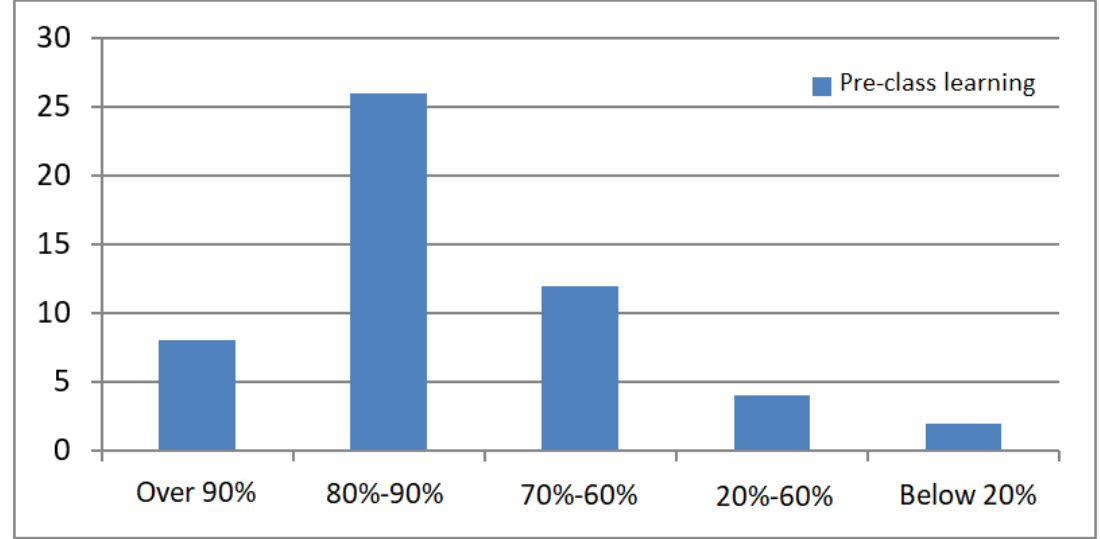

Fig. 3. Statistics of pre-class learning of students in experimental group

Finally, this kind of teaching mode has achieved initial results, as shown in Fig. 5, and more than $90 \%$ of the students recognized the teaching reform of this course, indicating that this new teaching mode is showing vigorous vitality, but still lacks more empirical studies to promote formal and informal learning of students [22]. It is expected that the application effect of the micro course teaching mode can be verified in the continuous exploration of teachers. 


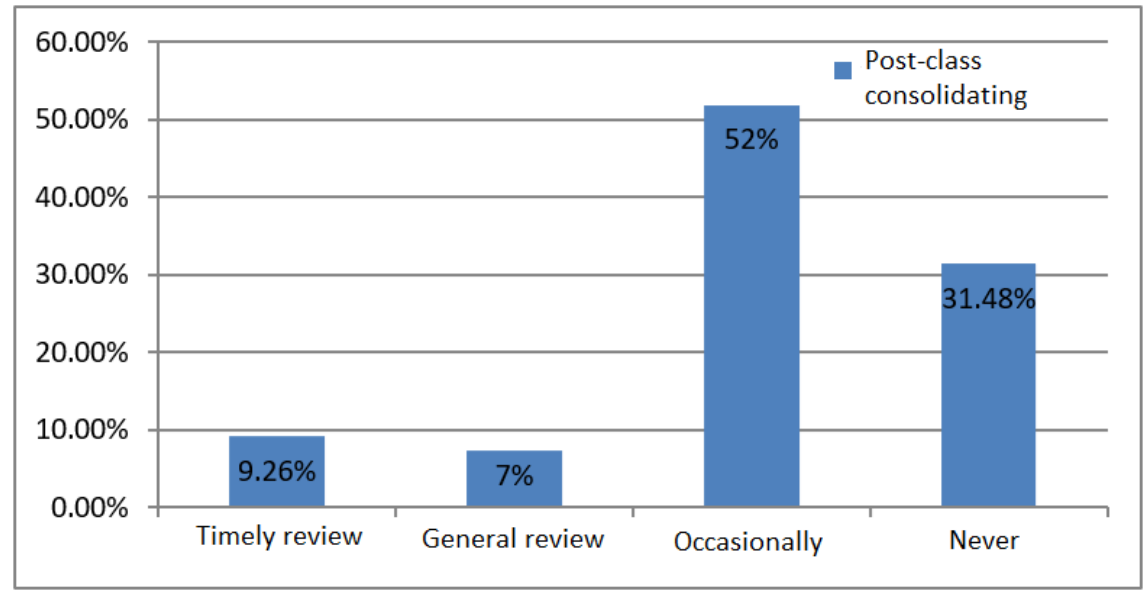

Fig. 4. Status of post-class review of students

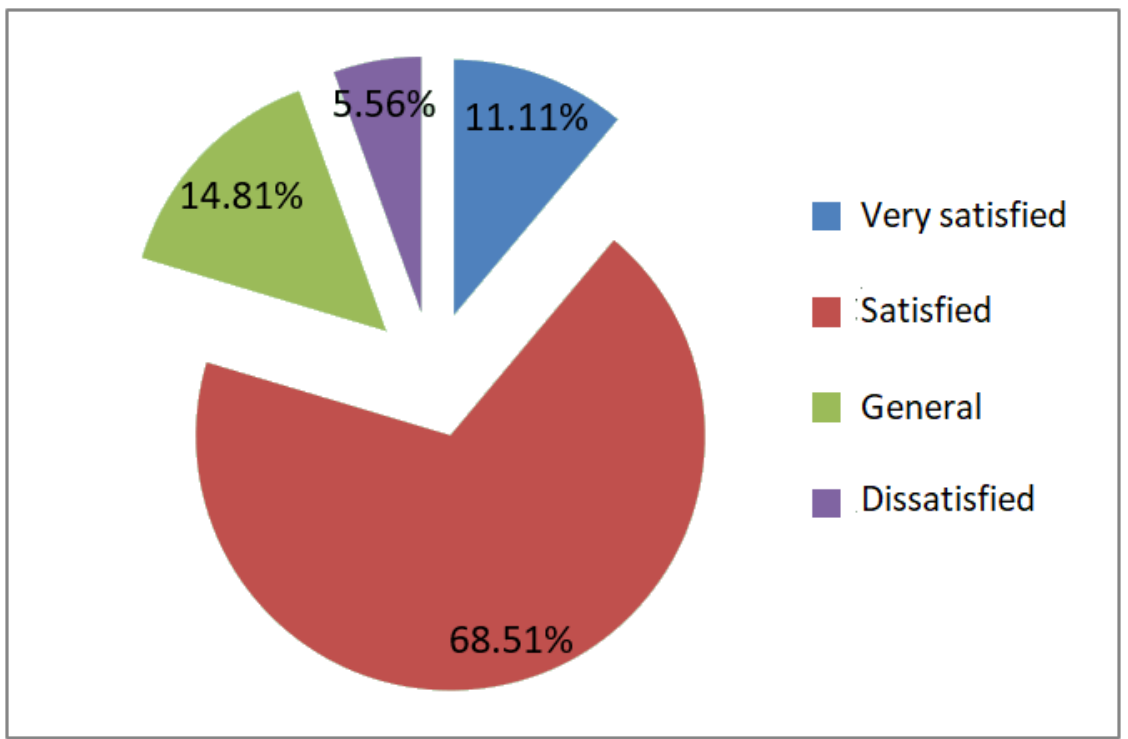

Fig. 5. Student recognition of the course

The construction and application of micro course deepens the teachers' idea of information-based teaching, raises the enthusiasm of teachers in their study and work, is conducive to the cultivation of teachers' professional knowledge, improves teaching means and enhances individual teaching level; more importantly, it has solved many practical difficulties and problems faced by the course of Fundamentals of Computers and raised the information teaching level of our university. At the same time, for the students, this teaching mode can reflect the process of students' active learning, highlight the students' dominant position in the process of learning, stimulate their 
enthusiasm for independent learning, and cultivate students' comprehensive computer application capability and information literacy.

In the future specific applications, teachers should adjust and grasp flexibly the teaching mode according to the actual situation of each group of students, sort out and update it in time, provide students with corresponding micro course resources in time, adjust teaching schedule and pay more attention to problems and the progress of students so as to improve the overall effect of teaching.

\section{$7 \quad$ Acknowledgement}

Fund Project: 2016 Project of Shaanxi Education Science "13th Five-Year Plan" (SGH16H229).

\section{$8 \quad$ References}

[1] Liu, X.H., Li, K.M. (2016). Application Research of the Microlecture Teaching Model in the Higher Vocational Education and Teaching Reform. International Conference on Information Technology in Medicine \& Education. IEEE. https://doi.org/10.1109/itme.2016. $\underline{0105}$

[2] Li, P. (2019). Applied research on flipped classroom teaching design based on "micro-lesson" in vocational English teaching -- a case study of hybrid teaching model in nanjing vocational college of mechanical and electrical technology. Contemporary education practice and teaching research, (24): 22-23. https://doi.org/10.35532/jsss.v3.029

[3] Liu, Y.J., Zhao, J.G., Wu, Y.F., Wang, W.P. (2019). Design of hybrid teaching course of environmental chemistry based on micro-class and flipped classroom. Guangdong chemical industry \& technology, 46(12): 175-176.

[4] Rahmelina, L., Firdian, F., Maulana, I.T., Aisyah, H., Na'am, J. (2019). The effectiveness of the flipped classroom model using e-learning media in introduction to information technology course. International Journal of Emerging Technologies in Learning, 14(21): 148-162. https://doi.org/10.3991/ijet.v14i21.10426

[5] Serik, M., Mukhambetova, M., Yeskermessuly, A. (2019). Improving the content of a clientserver technology training course: Set up and collaborative implementation of local and cloud-based remote servers, International Journal of Emerging Technologies in Learning, 14(21): 191-204. https://doi.org/10.3991/ijet.v14i21.10643

[6] Ghazi Tabatabaee, M., Yousefi Afrashteh, M., Siami, L. (2014). Evaluation of Student Learning Approaches and How They Tend to: Application of Mixed Research. quarterly journal of research \& planning in higher education, 19(4): 27-50.

[7] Xu, Y.S., Lv, Q.S., Ye, Y., Wu, M.C., Gu, J.H. (2017). Exploration and practice for engineering innovative talents training based on project-driven. 14th Conference on Education and Training in Optics and Photonics, ETOP 2017. https://doi.org/10.1117/12.2266487

[8] Pei, J.Y., Shan, P. (2019). A micro-expression recognition algorithm for students in classroom learning based on convolutional neural network. Traitement du Signal, 36(6): 557563. https://doi.org/10.18280/ts.360611

[9] Ren, H.J., Jia, S.Y., Wei, D., Luo, Y.P. (2017). Comparison and Application Among Micro Course, Massive Open Online Course and Flipped Classroom--Taking "Automotive 
Insurance and Claims" Course as an Example. Science Journal of Education, 5(3): 82-85. https://doi.org/10.11648/j.sjedu.20170503.11

[10] Venugopal-Wairagade, G. (2016). Study of a Pedagogy Adopted to Generate Interest in Students Taking a Programming Course. International Conference on Learning \& Teaching in Computing \& Engineering. IEEE, 2016. https://doi.org/10.1109/latice.2016.27

[11] An, S.F., Li, W.B., Hu, J.C., Ma, L.X., Xu, J.W. (2017). Research on the reform of flipped classroom in computer science of university based on SPOC. 2017 12th International Conference on Computer Science and Education (ICCSE), 621-625. https://doi.org/10.1109/iccse.2017.8085567

[12] Fang, N., Zhao, X. (2013). A comparative study of motivation and learning strategies between American and Chinese undergraduate engineering students. Frontiers in Education Conference. IEEE, 2013. https://doi.org/10.1109/fie.2013.6685127

[13] Elnagar, A., Ali, M.S. (2013). Survey of Student Perceptions of a Modified Team Based Learning Approach on an Information Technology Course. Palestinian International Conference on Information \& Communication Technology. IEEE Computer Society, 2013. https://doi.org/10.1109/picict.2013.14

[14] Peng, Y. (2019). Application of Micro-lecture in Computer Teaching. IOP Conference Series: Earth and Environmental Science, 234(1): 012053. https://doi.org/10.1088/1755$\underline{1315 / 234 / 1 / 012053}$

[15] Cheng, L. (2016). A study of Chinese engineering students' communication strategies in a mobile-assisted professional development course. Eurocall Review, 24: 24-31. https://doi.org/10.4995/eurocall.2016.6467

[16] Qin, J.Y., Bao, J.W., Yue, W.A. (2018). Teaching Research on the Basic Platform of Wechat Assisted Design, Design.

[17] He, X. (2018). Research on the Design and Application Strategy of Micro-course Teaching Mode Based on MOOC Environment_ - Taking the Cross-border E-commerce Course in Higher Vocational Education as an Example, Changchun, Jilin, China. https://doi.org/10. 25236/icemit.2018.328

[18] Wang, L.W., Huang, X. (2017). Research on the blended teaching mode of "basic computer science" based on "MOOC + virtual experiment". 2017 12th International Conference on Computer Science and Education (ICCSE). IEEE, Houston, TX, USA, 22-25. https://doi.org/10.1109/iccse.2017.8085558

[19] Venkatapathy, A.K.R. (2015). Study on Methodology and Implementation of Flipped Classroom Teaching for Engineering Courses. Proceedings of the International Conference on Transformations in Engineering Education. Springer India, 535-540. https://doi.org/10. $\underline{1007 / 978-81-322-1931-6 \quad 61}$

[20] Scheg, A.G. (2015). Implementation and Critical Assessment of the Flipped Classroom Experience. IGI Global, 25-40. http://dx.doi. org/10.4018/978-1-4666-7464-6

[21] Indi, T.S. (2016). An Experience Report of Flipped Classroom Strategy Implementation for Java Programming Course. IEEE Eighth International Conference on Technology for Education. IEEE, 2017. https://doi.org/10.1109/t4e.2016.059

[22] Wolfson, M.A., Mathieu, J.E., Tannenbaum, S.I., Maynard, M.T. (2019). Informal fieldbased learning and work design. The Journal of applied psychology, 104(10). https://doi. $\underline{\text { org/10.1037/apl0000408 }}$ 


\section{Author}

Hongxia Liu is a Master of Science and Associate professor of computer science. She graduated from the Shaanxi Normal University in 2004.Hongxia worked in Shaanxi Yulin University.Her research interests include Internet of Things scenarios, Data Mining and Computer Network.

Article submitted 2020-04-01. Resubmitted 2020-05-05. Final acceptance 2020-05-07. Final version published as submitted by the authors. 